\title{
Life without double-headed non-muscle myosin II motor proteins
}

\author{
Venkaiah Betapudi ${ }^{1,2 *}$ \\ ${ }^{1}$ Department of Cellular and Molecular Medicine, Lerner Research Institute, Cleveland Clinic, Cleveland, OH, USA \\ 2 Department of Physiology and Biophysics, Case Western Reserve University, Cleveland, OH, USA
}

\author{
Edited by: \\ Jianjun Chen, University of Chicago, \\ USA \\ Reviewed by: \\ Christian Stock, University of \\ Muenster, Germany \\ Jianfeng Chen, Chinese Academy of \\ Sciences, China \\ *Correspondence: \\ Venkaiah Betapudi, Department of \\ Cellular and Molecular Medicine \\ (NC10), Cleveland Clinic, Lerner \\ Research Institute, 9500 Euclid \\ Avenue, Cleveland, OH 44195, USA \\ e-mail: betapuv@ccf.org; \\ vxb19@case.edu
}

Non-muscle myosin II motor proteins (myosin IIA, myosin IIB, and myosin IIC) belong to a class of molecular motor proteins that are known to transduce cellular free-energy into biological work more efficiently than man-made combustion engines. Nature has given a single myosin II motor protein for lower eukaryotes and multiple for mammals but none for plants in order to provide impetus for their life. These specialized nanomachines drive cellular activities necessary for embryogenesis, organogenesis, and immunity. However, these multifunctional myosin II motor proteins are believed to go awry due to unknown reasons and contribute for the onset and progression of many autosomal-dominant disorders, cataract, deafness, infertility, cancer, kidney, neuronal, and inflammatory diseases. Many pathogens like HIV, Dengue, hepatitis C, and Lymphoma viruses as well as Salmonella and Mycobacteria are now known to take hostage of these dedicated myosin II motor proteins for their efficient pathogenesis. Even after four decades since their discovery, we still have a limited knowledge of how these motor proteins drive cell migration and cytokinesis. We need to enrich our current knowledge on these fundamental cellular processes and develop novel therapeutic strategies to fix mutated myosin II motor proteins in pathological conditions. This is the time to think how to relieve the hijacked myosins from pathogens in order to provide a renewed impetus for patients' life. Understanding how to steer these molecular motors in proliferating and differentiating stem cells will improve stem cell based-therapeutics development. Given the plethora of cellular activities non-muscle myosin motor proteins are involved in, their importance is apparent for human life.

Keywords: myosin II, motor proteins, molecular machines, cell migration, cytokinesis, cancer, pathogenesis, microparticles

\section{INTRODUCTION}

Machines are involved in driving virtually every aspect of modern human life, and so are myosin motor proteins in driving cellular life. Myosin motor proteins are specialized molecular machines that convert cellular free-energy into mechanical work (Bustamante et al., 2004). It is largely believed that the myosinperformed mechanical work intersects with almost every facet of cell biology. In fact, myosins play a central role in driving cellular activities that are necessary for singing a courtship song in flies, reproduction, childbirth, growth, development, and immunity as well as predisposing humans to a certain degree of risk for diseases (Stedman et al., 2004; Maravillas-Montero and SantosArgumedo, 2012; Slonska et al., 2012; Chakravorty et al., 2014; Min et al., 2014; Pecci et al., 2014).

The biological cell is equipped with a wide variety of motor proteins that are divided into cytoskeletal (myosin, kinesin, dynein), polymerization (actin, microtubule, dynamin), rotary $\left(\mathrm{F}_{0} \mathrm{~F}_{1}\right.$-ATP synthase), and nucleic acid (RNA and DNA polymerases, Helicase, Topoisomerases, RSC, SW1/SNF complex, SMC, viral DNA packaging protein) motor proteins to perform specific and dedicated cellular functions (Kolomeisky,
2013; Howard, 2014). Interestingly, these specialized molecular machines not only operate in a world where Brownian motion and viscous forces dominate but also work more efficiently than man-made combustion engines (van den Heuvel et al., 2007; Kabir et al., 2011). No biological cell can operate in the absence of these molecular machines. Most of these motor proteins are ubiquitously expressed but the expression of some of these motor proteins depends on cell and tissue type. The present review is about myosin motor protein, an essential component of the cytoskeletal system that is made up of proteins encoded by 441 genes in human. The human genome contains 40 genes that encode myosin motor proteins.

The term "myosin" (myo- + -ose + -in) means within muscle and was used to describe proteins with ATPase activity found originally in striated and smooth muscle cells (Pollard and Korn, 1973). The term "myo" was originated from "mys" to denote muscle in Greek. More than 140 myosins are reported in eukaryotes except in red algae and diplomonad protists (Vale, 2003). The majority of myosins have distinct head, neck, and tail domains and they are categorized into 35 different classes based on phylogenic analysis of their conserved heads, domain architectures, 
specific amino acid polymorphisms, and organismal distributions (Richards and Cavalier-Smith, 2005; Foth et al., 2006; Odronitz et al., 2007). Each class of myosins received a roman numeral. If more than one myosin of the same class is expressed in an organism, they are named in an alphabetical order according to their discovery. The present review is focused on current understanding and recent advances in various aspects of selected class II myosins as well as their regulation and relevance to human life and diseases.

\section{CLASS II MYOSINS (MYOSIN II)}

More than seven decades ago, an unknown myosin with ATPase activity was reported in the extracts of muscles (Engelhardt and Liubimova, 1994). Later, that unknown muscle myosin was identified as a class II myosin and then called conventional myosin and or the founding member of myosin super family. Class II myosins are expressed in all eukaryotes except plants. More than 34 class II myosins are reported in different organisms to date (Bagshaw, 1993). At least one myosin II is believed to be expressed in all eukaryotic cells. Based on motor or tail domain sequences and cell type expressions, class II myosins are further divided into four different sub-classes or groups. They are (1) Acanthamoeba or Dictyostelium myosins, (2) yeast myosins, (3) skeletal or cardiac or sarcomeric myosins, and (4) vertebrate smooth muscle or non-muscle myosins. Class II myosins are believed to be originated in unikonts that are ancestral eukaryotes with or without a single flagellum, including amoebozoans, fungi, and holozoans (Richards and Cavalier-Smith, 2005). While simple unicellular organisms like amoeba adopted a single myosin II gene, complex multicellular organisms except Drosophila acquired multiples of them during evolution. The human genome has over 40 myosin genes, and 15 of them are class II myosin genes $(M Y H 1$, MYH2, MYH3, MYH4, МYH6, МYH7, МYH7B, МYH8, МYH9, MYH10, MYH11, MYH13, MYH14, MYH15, MYH16) but not all of them are active (Berg et al., 2001). MYH11 encodes myosin II in smooth muscles but its splice variants result in four distinct isoforms (Matsuoka et al., 1993). MYH9, MYH10, and MYH14 located on different chromosomes encode myosin IIA, myosin IIB, and myosin IIC, respectively (Figure 1). These myosin II motor proteins are expressed exclusively in non-muscle cells, therefore called non-muscle myosin II motor proteins (Simons et al., 1991; Toothaker et al., 1991; Leal et al., 2003; Golomb et al.,

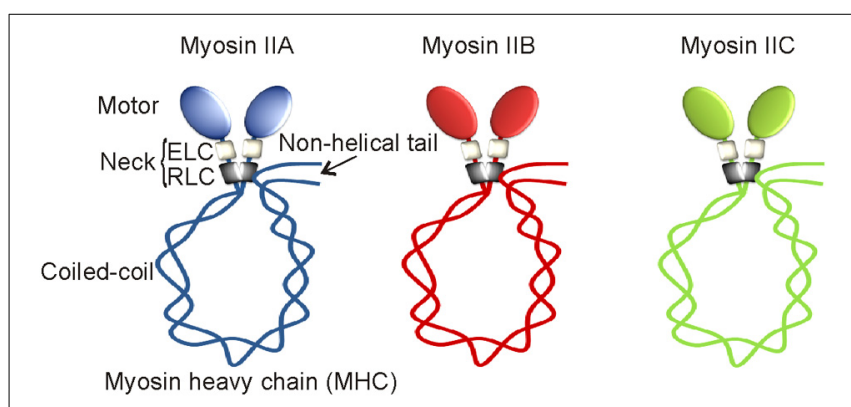

FIGURE 1 | Non-muscle myosin II motor proteins. Schematic representation of myosin II motor proteins that exist as complexes in cells.
2004). Myosin IIA, myosin IIB, and myosin IIC are expressed in every human non-muscle cell with a few exceptions; however, their expressions depend on cell and tissue types (Kawamoto and Adelstein, 1991; Golomb et al., 2004). No tissue or cell type appears to express all three non-muscle myosin II motor proteins but many cell types express at least one or two of them under normal physiological conditions. Myosin IIA and myosin IIB are expressed in endothelial and epithelial cells at similar levels. However, myosin IIB and myosin IIC are expressed abundantly in nervous and lung tissue, respectively. Myosin IIA is the only conventional myosin II motor protein expressed in the circulating platelets. Thus, preferential expression of myosin II motor proteins in different cell types reflects their specialization in mediating separate, dedicated, and probably non-redundant cellular functions. Why doesn't a single cell or tissue type express all three myosin II motor proteins is yet to be clearly understood. Perhaps, the cell specific expression of myosin II paralogs is critical for maintaining different cell and tissue types.

Myosin II motor proteins are mostly found in the cytoplasm of quiescent cells except in the nuclei of proliferating myoblasts (Rodgers, 2005). The cytosolic myosin II motor proteins undergo transient localization to contractile ring during cytokinesis. Myosin II motor protein using ATP as a cytosolic fuel generates mechanical forces required for separation of daughter cells during cytokinesis. However, the specific roles and underlying mechanisms of myosin II paralogs during cytokinesis are not clearly understood. The functional and mechanical roles of non-muscle myosin II motor proteins are extensively investigated in migrating cells for the past two decades. Many laboratories reported myosin IIA and myosin IIB with specific roles in mediating cell shape changes and interaction with matrix during migration. Cells prefer to make periodic extension and retraction of their lamellipodia during migration by unknown mechanisms. Interestingly, myosin IIA and myosin IIB motor proteins localize distinctly in the lamellipodia of migrating cells. On one hand, myosin IIB promotes lamellipodia and growth cone extensions and on the other, myosin IIA drives retraction of cell membrane during cell migration (Rochlin et al., 1995; Brown and Bridgman, 2003; Betapudi, 2010). The specific roles of myosin IIC motor protein in driving cell migration are not clearly understood. Myosin II activity is necessary for keratinocytes' migration, a critical step in the re-epithelialization of human skin wound (Betapudi et al., 2010). Myosin II motor proteins are also required for internalization of the cell surface receptors including EGFR and CXCR4 (Rey et al., 2007; Kim et al., 2012). Myosin IImediated mechanical forces have been implicated in operating the activity of contractile vacuoles to expel additional water and toxic materials from the soil-living amoeba in hypo-osmotic conditions (Betapudi and Egelhoff, 2009). Myosin II motor proteins have also been implicated in the mediation of viral infection (van et al., 2002; Arii et al., 2010), microparticle secretion (Betapudi et al., 2010), and cell death (Solinet and Vitale, 2008; Flynn and Helfman, 2010; Tang et al., 2011), however, their specific roles and underlying mechanisms remain unclear. Lower eukaryotes, such as amoeba can survive with certain developmental defects in the absence of myosin II (Xu et al., 1996) but the expression of all three myosin II motor proteins are necessary for 
mouse embryo growth and development (Conti and Adelstein, 2008).

\section{NON-MUSCLE MYOSIN II COMPLEX}

In line with multiple components involved in the assembly of man-made machines, biological cells also build their molecular machines using multiple polypeptides that are encoded by different genes. For instance, myosin II motor protein exists as a complex consisting of six non-covalently associated polypeptides that are encoded by a single myosin II and two different nonmyosin genes. Each myosin II complex with $525 \mathrm{kDa}$ molecular weight is composed of a myosin II heavy chain (MHC) homodimer, two essential light chains (ELC), and two regulatory light chains (RLC). Based on their extraction methods, ELC and RLC are also called alkali and 5,5'-dithiobis/2-nitrobenzoate (DTNB) light chains, respectively. While MHC with $226 \mathrm{kDa}$ molecular weight is encoded by a myosin II gene, both ELC with $16 \mathrm{kDa}$ and RLC with $22 \mathrm{kDa}$ molecular weights are considered as nonmyosin proteins of myosin II complex. Both ELC and RLC are commonly found in all myosin II complexes. Alternatively spliced MHC, ELC, and RLC are known to be expressed in certain tissue but our current knowledge on their specificities is still limited. Both heavy and light chain peptides undergo the UCS (UNC45/Cro1/She4) chaperone-mediated proper folding and assembly regulation in order to form a functional myosin II complex in the Golgi apparatus (Gazda et al., 2013; Hellerschmied and Clausen, 2013). This understudied complicated assembly process is common for all three myosin II motor proteins remains elusive. Transcriptional regulations of ELC and RLC are not clearly understood; however, MHC expressions of all three myosin II motor proteins are under the control of house-keeping promoters having no TATA elements (Kawamoto, 1994; Weir and Chen, 1996). However, differential expressions of MHCs were observed in response to serum and mitotic stimulants (Kawamoto and Adelstein, 1991; Toothaker et al., 1991). Elevated levels of MHCs were found in many types of tumor tissues (our unpublished results) but their underlying mechanisms are not clearly understood.

The MHC of class II myosins can be subdivided into distinct head, neck, and tail functional domains. Except C-terminal tail pieces, the MHCs of myosin IIA, myosin IIB, and myosin IIC share a significant protein sequence similarity in their motor domains. The N-terminal catalytic globular head or motor domain has binding sites for actin and ATP. Motor domain is also called the functional engine of myosin II motor protein. Myosin II motor domain undergoes an ATP-dependent conformational change in order to control its interaction with actin filaments, a key element of the cell strategy to convert cellular free-energy into protein motion or mechanical work. Despite having a significant sequence similarity, myosin II motor domains carry different binding affinities for actin filaments. Thus, myosin IIA, IIB, and IIC are believed to perform mechanical work with different energetic efficiencies in cells. Myosin II motor domain is followed by a neck region consisting of two conserved IQ motifs (IQxxxRGxxxR); however, myosins of other classes may have more or less than two IQ motifs (Cheney and Mooseker, 1992). IQ motifs form an amphiphilic uninterrupted seven-turn $\alpha$-helix with binding affinity for either light chains or calmodulin in $\mathrm{Ca}^{+2}$-independent manner. ELC and RLC occupy the first and second IQ motifs of the neck region, respectively. ELC binds IQ motif to give stability for MHC; however, RLC offers both stability and functional regulation to MHC. IQ domain allows light chains to acquire either compact or extended conformation. Thus, neck region with light chains attached acts as a linker and lever arm for myosin II motor domain to amplify energy conversion into mechanical work. The length of the neck region is believed to have direct impact on myosin II motor speed and energy transduction into mechanical work (Uyeda et al., 1996). The neck region of all myosins have IQ motifs except class XIV Toxoplasma myosin A (Heintzelman and Schwartzman, 1997). IQ motif with approximately 25 amino acids in length is widely distributed in nature, thus, ELC also binds other myosins of class V, VI, and VII as well as non-myosin proteins carrying IQ motifs, but RLC exclusively binds to myosins of class II and XVIII (Chen et al., 2007; Tan et al., 2008). Myosin II neck region is followed by a tail domain with variable amino acid sequences. The tail domain with coiledcoil $\alpha$-helices terminates into a short non-helical tailpiece. The coiled-coil tail domain undergoes homodimerization to form a single rod-like structure. Thus, myosin II complex has two globular heads or motor domains with a single coiled-coil rod-like structure hence called double-headed myosin II motor protein. Myosin II complex attains a compact folded conformation due to a "proline-kink" at the junction of head and rod domains, and attachment of its C-terminal tail domain to RLC as depicted in Figure 1 (Onishi and Wakabayashi, 1982; Trybus et al., 1982; Craig et al., 1983). Thus, the myosin II complex with compact folded structure sediments at $10 \mathrm{~S}$ (Svedberg) and therefore called $10 \mathrm{~S}$ form. The myosin II complex in $10 \mathrm{~S}$ form shows high binding affinity for ADP and inorganic phosphate (Pi), and virtually no enzyme activity (Cross et al., 1986, 1988). However, the activated myosin II complex exists in an elongated conformation due to its C-terminal tail detachment from RLC. The activated myosin II complex in an elongated form sediments at $6 \mathrm{~S}$ and therefore called 6S form (Trybus and Lowey, 1984). Myosin II motor proteins with elongated conformation tend to assemble into highly ordered parallel and anti-parallel thick filaments due to intermolecular interactions between coiled-coil tail domains. Interestingly, myosin II tail domains form large aggregates without proper filamentation in the absence of RLC (Pastra-Landis and Lowey, 1986; Rottbauer et al., 2006). Thus, RLC-controlled tail-domain filamentation and motor domain interaction with actin filaments are the most important aspects of cell strategy for converting ATP released free-energy into force and mechanical work using myosin II motor proteins.

\section{RLC PHOSPHORYLATION IN REGULATING MYOSIN II ACTIVITY}

Myosin IIA, myosin IIB, and myosin IIC paralogs with 60-80\% sequence similarity at the amino acid level and same quaternary structure appear to be diverged from a common ancestor more than 600 million years ago, however, they display different regulatory mechanisms under normal physiological conditions (Jung et al., 2008). Role of RLC phosphorylation in regulating myosin II activity in many cell and tissue types is extensively investigated 
since its discovery in rabbit skeletal muscle myosins more than three decades ago (Casadei et al., 1984). RLC perhaps does not exist alone but when remains associated with the neck region of MHC undergoes reversible phosphorylation on its S1, S2, T9, $\mathrm{T} 18$, and $\mathrm{S} 19$ amino acids in order to turn-on and turn-off myosin II motor complexes in cells (Figure 2). RLC phosphorylation on S19 alone or on both T18 and S19 amino acids turns-on myosin II motor complex by increasing its ATPase activity and extended $6 \mathrm{~S}$ conformation that allows simultaneous assembly into thick filaments (Wendt et al., 2001; Somlyo and Somlyo, 2003; Betapudi et al., 2006, 2010). However, RLC phosphorylation does not affect myosin II motor domain affinity for actin filaments (Sellers et al., 1982). RLC phosphorylation on S1, S2, and S9 or dephosphorylation on T18 and S19 amino acids turns-off myosin II complex by allowing acquisition of monomeric $10 \mathrm{~S}$ compact conformation and no filamentation.

RLC reversible phosphorylation is tightly regulated by both myosin specific phosphatase and a wide variety of kinases including myosin light chain kinase (MLCK/MYLK), Rho-associated coiled-coil-containing kinase (ROCK), leucine zipper interacting protein kinase (ZIPK) or death associated protein kinase 3 (DAPK3), citron kinase or citron rho-interactive kinase (CRIK) or Serine/threonine-protein kinase 21 (STK21), myotonic dystrophy kinase-related CDC42-binding kinase (MRCK/CDC42BP). These kinases are known to phosphorylate RLC on T18 and S19 amino acids to activate myosin II complexes in different cell types. Protein kinase C (PKC) phosphorylates S1, S2, and S3 amino acids to inactivate myosin II in dividing cells (Nishikawa et al., 1984; Varlamova et al., 2001; Beach et al., 2011). Interestingly, all these kinases display specific intracellular localizations and respond to a wide variety of signal transduction pathways in order to phosphorylate RLC and activate myosin II motor proteins in many cell types. MLCK in response to $\mathrm{Ca}^{+2}$-calmodulin activates myosin II that is localized next to cell membrane (Totsukawa et al., 2004). The site-specific intracellular localization and activity of MLCK are regulated by several kinases including p21 activated kinase 1 (PAK1), Abl tyrosine kinase, Src, and arrest defective 1 in many cell types (Sanders et al., 1999; Dudek et al., 2004; Shin et al., 2008). RhoA, a small GTP-binding protein activates both ROCK and citron kinase in the central part of cell. The actin binding protein, Shroom 3 directs ROCK intracellular

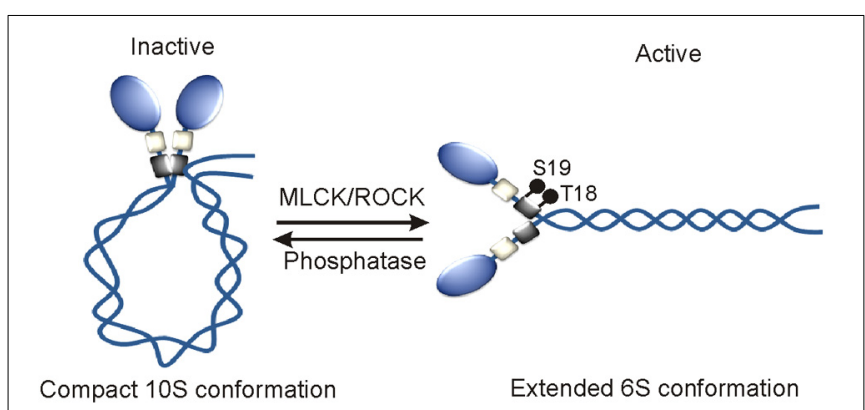

FIGURE 2 | Mechanism of the activation of myosin II motor proteins. RLC phosphorylation by MLCK and ROCK or other kinases turns on myosin II motor protein in vivo. localization, and RLC phosphorylation in neuroepithelial cells (Haigo et al., 2003; Hildebrand, 2005). DAPK3 predominantly displays nuclear localization and phosphorylates RLC in the cells that are undergoing apoptosis in $\mathrm{Ca}^{2+} /$ calmodulin-independent manner (Murata-Hori et al., 1999). PKC phosphorylates RLC in the presence of $\mathrm{Ca}^{+2}$ and DAG (diacylglycerol) and or phorbol esters in mitotic cells (Varlamova et al., 2001). Both intracellular site-specific RLC reversible phosphorylation and myosin II activation are tightly controlled by protein phosphatase 1 (PP1), a ubiquitously expressed myosin specific phosphatase (Xia et al., 2005; Matsumura and Hartshorne, 2008; Rai and Egelhoff, 2011). All the regulators of RLC phosphorylation are also known to phosphorylate other substrates in cells. For instance, MLCK is implicated in phosphorylating a proline-rich protein tyrosine kinase 2 (PYK2/PTK2B) or focal adhesion kinase 2 (FAK2) that is involved in promoting lung vascular endothelial cell permeability during sepsis (Xu et al., 2008). ROCK also directly phosphorylates LIM kinase and MYPT1, a regulatory subunit of PP1 in many types of cells and tissues (Kimura et al., 1996; Leung et al., 1996). MYPT1 phosphorylation inactivates PP1 and this leads to a marked increase in RLC phosphorylation and myosin II activation. MYPT1 phosphorylation is also regulated by ZIPK, MRCK, and PKC in many cell and tissue types. PKC also phosphorylates MHC to regulate myosin II activity in cells under normal physiological conditions. MLCK-A is the only RLC phosphorylating kinase identified in Dictyostelium to date (Tan and Spudich, 1990). Unlike MLCK in mammalian cells, MLCK-A phosphorylates S13 of RLC in the absence of $\mathrm{Ca}^{+2}$-calmodulin (Tan and Spudich, 1990). The RLC phosphorylation on S13 amino acid increases myosin II motor activity and regulates cell morphological changes without affecting normal growth and development of amoeba (Griffith et al., 1987; Chen et al., 1994; Uyeda et al., 1996; Liu et al., 1998; Matsumura, 2005). Except reversible phosphorylation, no other posttranslational modification of RLC that has a role in regulating myosin II activity is known to date.

\section{MHC PHOSPHORYLATION IN REGULATING MYOSIN II ACTIVITY}

MHC phosphorylation was first reported in macrophages in the early 1980s and after nearly a decade its role in regulating myosin II filamentation and localization was documented in lower eukaryotes like Acanthamoeba and Dictyostelium disoideum (Collins and Korn, 1980; Kuczmarski and Spudich, 1980; Trotter, 1982; Kuznicki et al., 1983; Trotter et al., 1985; Barylko et al., 1986; Pasternak et al., 1989; Egelhoff et al., 1993). According to computational prediction of phosphorylation sites, the heavy chains of myosin IIA, IIB, and IIC appear to undergo phosphorylation on multiple residues in the head, neck, and tail domains; however, only a few sites in the coiled-coil and nonhelical tail regions of their $\mathrm{C}$-terminal ends are reported to date. The MHC of myosin IIA undergoes phosphorylation on T1800, S1803, and S1808 in the coiled-coil and on S1943 residues in the non-helical tail regions (Figure 3). Myosin IIB and myosin IIC heavy chains also undergo phosphorylation on multiple sites in the coiled-coil and non-helical tail regions of their C-terminal ends (Dulyaninova and Bresnick, 2013). Many kinases including 


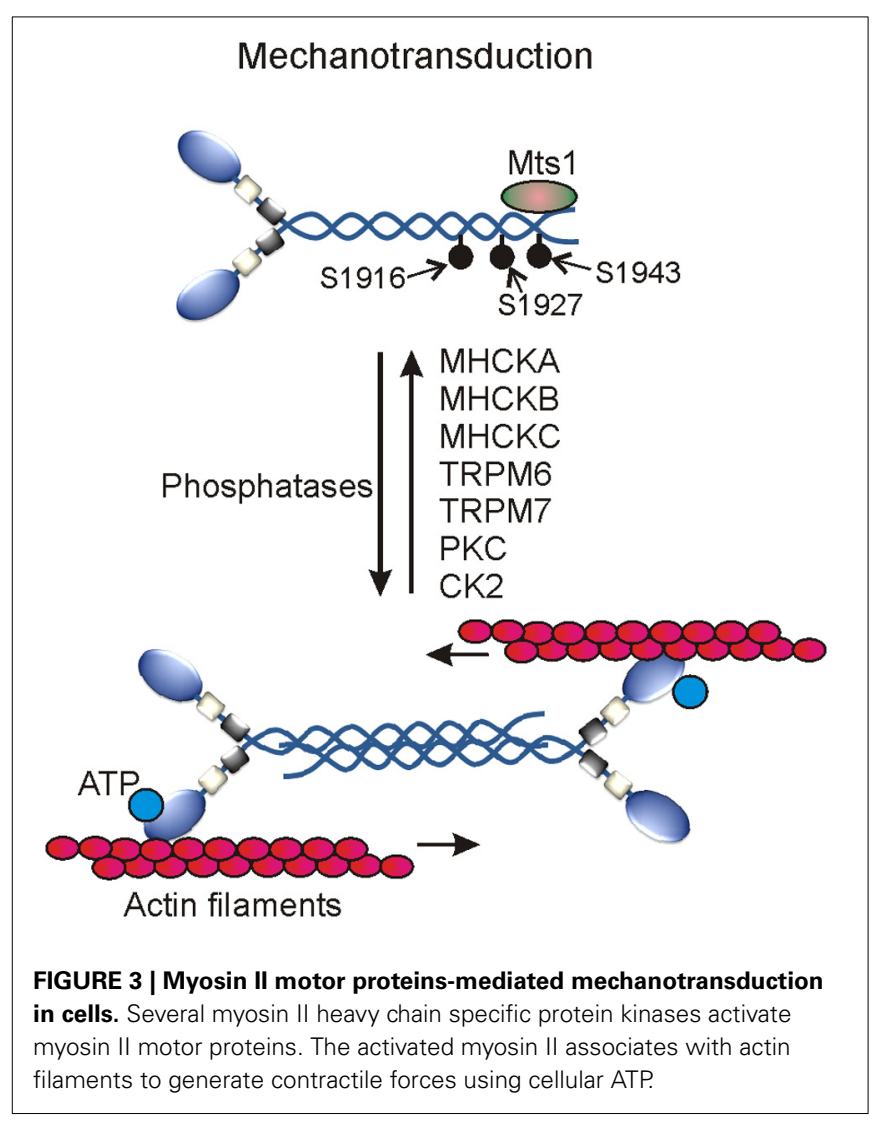

casein kinase 2 (CK2), the members of PKC as well as alphakinase family are involved in phosphorylating C-terminal ends of all three MHCs in normal physiological and pathological conditions (Murakami et al., 1998; Dulyaninova et al., 2005; Clark et al., 2008a,b; Ronen and Ravid, 2009). PKC members are involved in phosphorylating S1916 and S1937 residues of myosin IIA and myosin IIB, respectively (Conti et al., 1991; Even-Faitelson and Ravid, 2006). PKC is also involved in phosphorylating other multiple serine residues in myosin IIB and threonine residues in myosin IIC coiled-coil regions (Murakami et al., 1998; Ronen and Ravid, 2009). CK2 is known to phosphorylate $\mathrm{S} 1943$ residue in the non-helical tail region of myosin IIA in vitro. CK2 was implicated in the regulation of myosin II assembly and localization especially in pathological conditions. However, neither chemical inhibition nor siRNA-mediated depletion of CK2 showed any effect on S1943 phosphorylation or breast cancer cell migration on fibronectin coated surfaces (Betapudi et al., 2011). CK2 is also involved in phosphorylating multiple residues in the coiledcoil and non-helical tail regions of myosin IIB and myosin IIC (Murakami et al., 1998; Ronen and Ravid, 2009; Rosenberg et al., 2013). Thus, CK2 clearly plays a critical role in regulating myosin II-mediated cellular functions in other pathological conditions.

In addition to PKC and CK2, several members of the alphakinase family are involved in phosphorylating myosin II heavy chains in mammals and Dictyostelium discoideum. Alpha kinases belong to a small and unique group of protein kinases with catalytic domains having a little or no similarity at amino acid level with the catalytic domains of conventional protein kinases
(Ryazanov et al., 1999; De la Roche et al., 2002; Drennan and Ryazanov, 2004; Scheeff and Bourne, 2005; Middelbeek et al., 2010). Conventional protein kinases usually find their phosphorylating sites in $\beta$-turns, loops, and irregular structures of their substrates; however, the first member of the alpha-kinase family prefers to phosphorylate amino acids located in the $\alpha$-turns of their cellular targets hence called $\alpha$-kinases (Vaillancourt et al., 1988; Luck-Vielmetter et al., 1990). But recent in vitro phosphorylation studies showed that alpha-kinases also target residues present in the non-alpha helical structures of their cellular substrates (Jorgensen et al., 2003; Clark et al., 2008a). Members of the alpha-kinase family are identified only in eukaryotes to date (Ryazanov et al., 1999; Scheeff and Bourne, 2005). Transient receptor potential melastatin 6 (TRPM6) and Transient receptor potential melastatin 7 (TRPM7) kinases are among the total six alpha-kinases identified in human to date. TRPM6 and TRPM7 kinases belong to a large protein family of transient receptor potential cation channels that are involved in sensing mechanical stress, pain, temperature, taste, touch, and osmolarity (Ramsey et al., 2006; Middelbeek et al., 2010; Su et al., 2010; Runnels, 2011; Mene et al., 2013). Both TRPM6 and TRPM7 kinases phosphorylate T1800, S1803, and S1808 residues in the coiledcoil region of MHC to control myosin IIA filamentation and association with actin filaments (Clark et al., 2008a,b). These multifunctional kinases also phosphorylate several residues in the non-helical tail regions of myosin IIB and myosin IIC to control myosin II filamentation. MHC undergoes phosphorylation on T1823, T1833, and T2029 residues in the tail region of myosin II in Dictyostelium (De la Roche et al., 2002). Phosphorylation of these sites controls myosin II filamentation and plays critical roles in regulating growth and development of Dictyostelium. Except vWKa kinase, all other identified alpha-kinase family members including MHCK-A, MHCK-B, MHCK-C, and MHCK-D are involved in phosphorylating these sites in Dictyostelium (Egelhoff et al., 2005; Yumura et al., 2005; Underwood et al., 2010). Although vWKa does not directly phosphorylate MHC in vitro but regulates myosin II expression and filamentation in cells by unknown mechanism (Betapudi et al., 2005). Unlike other alpha kinases involved in regulating myosin II, vWKa displays specific sub-cellular localization to contractile vacuoles that are known to expel toxic metals and excess water from the cytoplasm of amoeba. Though the underlying mechanisms are yet to be uncovered, the myosin II-mediated mechanical work has been implicated in regulating the dynamics of contractile vacuoles and survival of Dictyostelium discoideum in abnormal osmotic conditions (Betapudi and Egelhoff, 2009). vWKa regulates myosin II expression and filament disassembly by unknown mechanisms to protect amoeba from osmotic shock death (Betapudi and Egelhoff, 2009). Phosphatases specific to the heavy chains of myosin II motor proteins are yet to be identified in mammals.

Many proteins including S100A4, lethal giant larvae ( $\mathrm{Lgl})$, myosin binding protein $\mathrm{H}$, and S100P bind MHCs to control phosphorylation and filament assembly of myosin II in flies and mammals (Kriajevska et al., 1994; Ford et al., 1997; Vasioukhin, 2006; Du et al., 2012; Hosono et al., 2012). Lgl is a tumor suppressor protein and forms a complex with C-terminal ends of the MHC of myosin II to control cell proliferation. However, the 
Lgl-myosin II complex dissociates when myosin II heavy chain is phosphorylated by PKC (Strand et al., 1994; Kalmes et al., 1996; Plant et al., 2003; Betschinger et al., 2005). Lgl binds coiled-coil regions of the MHC to control myosin II filamentation and localization (De et al., 1999; Dahan et al., 2012). Deletion of the Lgl located specific region in the human chromosome 17 has been implicated in the development of Smith-Magenis Syndrome, a developmental disorder that affects many body parts, intellectual disability, and sleep disturbances (Smith et al., 1986; Koyama et al., 1996; De et al., 2001). However, role of mutated Lgl in controlling myosin II phosphorylation and cellular functions remains elusive. The metastasis factor mts 1 also called S100A4 or calvasculin, a member of the $\mathrm{S} 100$ family of calcium-binding proteins, binds C-terminal ends of the MHC of myosin II. Binding of S100A4 to C-terminal ends of the MHC promotes phosphorylation on S1943 and disassembly of myosin II filamentation; however, the underlying mechanisms remain unknown to date (Li et al., 2003; Badyal et al., 2011; Mitsuhashi et al., 2011; Kiss et al., 2012). S100-P, another member of S100 family of calcium-binding proteins and a novel therapeutic target for cancer, interacts with myosin II in cells. S100-P has been implicated in controlling myosin II filamentation and cell migration (Du et al., 2012). Myosin binding protein H (MYBPH) binds ROCK1 to control RLC phosphorylation and cell migration. MYBPH also binds MHC to control myosin II filamentation and cell migration; however, the underlying mechanisms are not clearly understood (Hosono et al., 2012). Recent studies suggest that the unassembled myosin II with phosphorylated RLC plays a role in the initiation of focal adhesion complexes formation and cell membrane extension (Shutova et al., 2012). It would be interesting to understand the coordinated regulation of RLC and MCH phosphorylation adopted by cell to regulate myosin II filamentation and cellular functions. Though the underlying mechanisms are not clearly understood, Tropomyosin, an integral part of the actin cytoskeleton system in cells has been implicated in regulating myosin II localization to plasma membrane and stress fiber formation (Bryce et al., 2003). Myosin II activity is also controlled by Supervillin, an actin filament binding and cell membrane associated scaffolding protein. Supervillin binds MLCK to control RLC phosphorylation and myosin II activity (Takizawa et al., 2007). Thus, non-muscle myosin II motor proteins are regulated by several proteins at multiple levels to perform dedicated cellular functions.

\section{MYOSIN II MOTOR PROTEINS IN PREDISPOSING HUMANS TO DISEASES}

Plants live normal life without class II myosins but mammals require these multifunctional molecular machines for survival and growth. Because the MYH9 germline-ablated mice without myosin IIA die on 6.5 embryonic day (E) due to defective cell-cell interaction and lack of polarized visceral endoderm (Conti et al., 2004). The MYH10 germline-ablated mice with no myosin IIB survive till E14.5 and then die due to brain and cardiac developmental defects (Tullio et al., 1997, 2001). However, the MYH14-ablated mice in the absence of myosin IIC can survive with no obvious defects till adulthood but require the expression of myosin IIB (Ma et al., 2010). Misregulation, mutations, and alternative splicing of MYH9, MY10, and MY14 predispose humans to the onset and progression of many diseases (Table 1). More than 45 mutations are identified in MYH9 to date and some of them are linked to a large number of autosomal-dominant disorders including May-Hegglin anomaly, Sebastian platelet syndrome, Fetchner syndrome, Bernard-Soulier syndrome, Alport syndrome, and Epstein syndrome. These diseases are collectively called MYH9-related diseases (MYH9RD) (Kelley et al., 2000; Burt et al., 2008; Pecci et al., 2008; Balduini et al., 2011). The MYH9RD patients with mutations in the motor domain (R702C/H and R1165C/L) of myosin IIA develop deafness, cataract, Döhle-like inclusions, nephritis, and thrombocytopenia with enlarged platelets in their middle age (Pecci et al., 2008, 2014; De et al., 2013). An estimated 30-70 percent of MYH9RD patients develop kidney disease in their early adulthood. Leukocytes of the MYH9RD patients carry non-functional myosin IIA clumps. However, patients carrying mutations in the tail domain of myosin IIA (D1424H/N/Y, V1516M, E1841K, R1933X) show no symptoms of clinical relevance (Pecci et al., 2010). The overexpression of myosin IIA is implicated in causing enhanced cancer cell migration and metastasis as well as lung and kidney tumor invasion (Gupton and Waterman-Storer, 2006; Derycke et al., 2011; Xia et al., 2012). However, this hypothesis is downplayed by recent reports on myosin IIA roles in the posttranscriptional stabilization of p53 activity and repression of squamous cell carcinoma in mice (Schramek et al., 2014). A chimeric MYH9-Alk transcript formed by the fusion of MYH9 and ALK (anaplastic lymphoma kinase) was observed in anaplastic large cell lymphoma but its disease relevance is yet to be established (Lamant et al., 2003). No mutation in MYH10 that is relevant to a disease with any clinical symptom is reported to date; however, recently an E908X de novo mutation is reported in patients with microcephaly, hydrocephalus, cerebral, and cerebellar atrophy. An indirect link in between the expression of myosin IIB and progression of several diseases including, megakaryopoiesis, myocardial infarction, scar tissue formation, demyelination, and juvenile-onset neuronal ceroid lipofuscinosis (JCNL) or Batten disease is established (AntonyDebre et al., 2012). Batten disease, a lysosomal storage disorder is caused by mutations in CLN3 that encodes a lysosomal membrane binding chaperone known to interact directly with myosin IIB. Mutations in CLN3 are believed to affect interaction with myosin IIB as well as retrograde and anterograde trafficking in the Golgi complexes (Getty et al., 2011). Patients carrying CLN3 mutations show symptoms of seizures, psychomotor disturbances, dementia, and loss of vision (Cotman and Staropoli, 2012). Patients carrying mutations in MYH14 are also linked to many diseases including hereditary blindness (DFNA4), hoarseness, peripheral neuropathy, and myopathy (Donaudy et al., 2004; Choi et al., 2011). In addition, patients expressing aberrant splicing products of MYH14 develop myotonic dystrophy type 1 (DM1), a progressive multisystem genetic disorder that affects 1 in 8000 people worldwide (Rinaldi et al., 2012; Kumar et al., 2013).

In addition, the overexpression of myosin II upstream regulators ROCK and Mts1 is implicated in spreading cancer (Sandquist et al., 2006; Boye and Maelandsmo, 2010; Kim and Adelstein, 
Table 1 | Defects and associated diseases of myosin II motor proteins and their regulators.

\begin{tabular}{|c|c|c|c|}
\hline Gene & Mutation/Defect & Disease & Common symptoms \\
\hline & $\begin{array}{l}\text { MYH9-Alk chimeric } \\
\text { Transcript** }\end{array}$ & Anaplastic large cell lymphoma & $\begin{array}{l}\text { Blood cancer, painless swelling of lymph } \\
\text { nodes, and rapid weight loss. }\end{array}$ \\
\hline & Overexpression $\$$ & Cancer metastasis & - \\
\hline & Downregulation & $\begin{array}{l}\text { Megakaryopoiesis, myocardial infarction, demyelination, Batten } \\
\text { disease }\end{array}$ & $\begin{array}{l}\text { Chest pain, dizziness, nausea, ocular } \\
\text { paralysis, speech problem, and impaired } \\
\text { vision. }\end{array}$ \\
\hline MYH14 & $\begin{array}{l}\text { S7X, S120L, G376C, } \\
\text { R726S, L976F }\end{array}$ & $\begin{array}{l}\text { Hereditary blindness, hearing impairment (DFNA4), peripheral } \\
\text { neuropathy, myopathy, hoarseness }\end{array}$ & $\begin{array}{l}\text { Deafness, loss of vision, burning pain, } \\
\text { numbness, changes in skin, hair or nail, } \\
\text { dizziness, and paralysis. }\end{array}$ \\
\hline ROCK & Overexpression $\$$ & Cancer metastasis & - \\
\hline Mts1 & Overexpression $\$$ & Cancer metastasis & - \\
\hline$D m / c 2^{\#}$ & $\Delta 2-46, \mathrm{~S} 66 \mathrm{~A}, \mathrm{~S} 67 \mathrm{~A}$ & Impairment of courtship & Inability of a fly to sing a courtship song. \\
\hline \multirow[t]{3}{*}{ MYLK } & G601E & Cancer & - \\
\hline & P147S & Asthma & - \\
\hline & SNP & Asthma, acute lung injury, sepsis & - \\
\hline$C L N 3^{@}$ & $\begin{array}{l}\text { L101P, L170P, Y199X, } \\
\text { Q295K }\end{array}$ & Seizures, dementia, and psychomotor disturbances & $\begin{array}{l}\text { Loss of vision and memory, mood swings, } \\
\text { poor judgment. }\end{array}$ \\
\hline
\end{tabular}

${ }^{*}$ Refer Burt et al. (2008), "*Found in the lymphocytes of lymphoma patients, \$Implicated, "Encodes RLC in Drosophila, @Interacts directly with myosin IIB, $\Delta$ deletion, SNP, single nucleotide polymorphism; ${ }^{\wedge}$ L Lgl, located region in chromosome 17.

2011). Mutations in RLC were shown to affect singing male courtship song in flies (Chakravorty et al., 2014). Mutations in RLC phosphorylating MYLK are linked to cancer (Greenman et al., 2007) and familial aortic dissections that may cause sudden death (Wang et al., 2010). A few race-specific single nucleotide polymorphism variants of MYLK are linked to asthma, acute lung injury and sepsis (Gao et al., 2006, 2007; Flores et al., 2007). Hypomagnesemia patients with secondary hypocalcemia carry mutations in TRPM6 that is known to regulate MHC phosphorylation (Schlingmann et al., 2002; Walder et al., 2002). Though the underlying mechanisms are not clearly understood, myosin II motor proteins are believed to be hijacked by many pathogens such as herpes simplex virus type 1 for egression (van et al., 2002; Arii et al., 2010), murine leukemia virus for infection (Lehmann et al., 2005), and Salmonella bacteria for growth in macrophages (Wasylnka et al., 2008). Kaposi's sarcoma herpes simplex virus that is known to cause AIDS related neoplasm manipulates c-Cbl and myosin II-mediated signaling pathway to induce macropinocytosis in order to infect blood vessels (Sharma-Walia et al., 2010). Some pathogens like HIV1 selectively down-regulates myosin IIA in kidney and cause renal disease probably to escape clearance through urine (Hays et al., 2012). Dengue virus type 2 activates Rac1 and Cdc42mediated signaling pathway to regulate myosin II for successful infection of host cells (Zamudio-Meza et al., 2009). Respiratory Syncytial Virus (RSV) that is known to cause severe respiratory tract infections is believed to activate actomyosin system for improved pathogenesis (Krzyzaniak et al., 2013). Pathogens like hepatitis $\mathrm{C}$ virus induce development of autoantibodies having binding affinity for myosin IIA perhaps as a part of escape strategy from host defense network (von Muhlen et al., 1995). 


\section{CONCLUSION AND PERSPECTIVES}

Molecular motor proteins are largely accepted as the most efficient transducers of cellular free energy into biological work that is critical for the sustenance of life. Class II myosins especially non-muscle myosin IIA, myosin IIB, and myosin IIC motor proteins are emerged as the main mechanotransducers of cellular-free energy that is necessary for driving multiple biological processes ranging from birth to death in mammals' life. During the past two decades, research on myosin II motor proteins was focused on understanding the underlying mechanisms of myosin IImediated mechanotransduction in many biological systems. It is also proven beyond reasonable doubt that murine life does not exist without the expression of non-muscle myosin II motor proteins (Conti and Adelstein, 2008). Interestingly, many patients with mutated myosin IIA, myosin IIB, and myosin IIC paralogs are reported but none without these biological nanomachines to date. The extrapolation of these findings with caution may suggest that life in mammals does not exist without the expression of non-muscle myosin II motor proteins. Therefore, the emergence of genes that encode non-muscle myosin II motor proteins perhaps is a turning point in the evolution of mammals. During this process, humans acquired three different genes Myh10, Myh11, and Myh14 with a significant homology in nucleotide sequence. It is generally believed that humans do require the expression of all three functional non-muscle myosin II motor proteins to maintain normal growth, development, and disease resistance. But why human cell and tissue types display differential expression of myosin II paralogs still remains unanswered. Part of the reasons could be due to their specialization in mediating dedicated functions that are specific to each cell and tissue type. However, this concept will benefit from further understanding of structural and posttranslational modifications of all three different myosin II complexes. Although we made progress in identifying several mutations in myosin II motors proteins and their regulating proteins, very little is known about the diseaserelevant mutations in myosin II motor proteins. Novel strategies for management and diagnosis of MYH9RD patients are required (Althaus and Greinacher, 2010). This area of research requires additional attention to gain more insights for the development of myosin II-based novel therapeutic approaches in future. Many modern cell biologists recognize myosin II motor proteins as key drivers of cell migration and cytokinesis that are known to go awry in cancer and other pathological conditions. Although overexpression of myosin II motor proteins has been implicated in driving cancer progression and metastasis, further understanding of their specific expression profiles in every cancer type will help designing therapeutic developments. Also, expanding our limited knowledge on the expression of chimeric as well as alternate splicing products of non-muscle myosin II motor proteins in pathological conditions will allow development of treatment options. During the past two decades, we made a very limited progress on understanding how pathogens hijack non-muscle myosin II motor proteins for their efficient infection and propagation. Understanding what made these dedicated molecular machines to work for the interests of pathogens is no less than a challenge to cell biologists in future. We are yet to understand how myosin II motor proteins mediate release of microvesicles that are known to make inter cellular communications and promote progression of many human diseases. Myosin II-mediated mechanotransduction has been implicated in the regulation of stem cell proliferation and differentiation (Chen et al., 2014). Additional efforts to understand the mechanical roles of myosin IIA, IIB, and IIC motor proteins will have a significant impact on stem cells-based tissue engineering, synthetic bioengineering, and therapeutic development.

\section{ACKNOWLEDGMENTS}

The present review article was written with a particular theme on non-muscle myosin II motor proteins. The author apologizes for the omission of any study that has direct relevance with the main theme of the present article. The present work would not have been possible without the mentorship of author's previous mentors Professors Seyed E. Hasnain and Thomas T. Egelhoff, and critical reading by Dr. Saurabh Chattopadhyay as well as private and public funding agencies including the U.S. National Institute of Health.

\section{REFERENCES}

Althaus, K., and Greinacher, A. (2010). MYH-9 related platelet disorders: strategies for management and diagnosis. Transfus. Med. Hemother. 37, 260-267. doi: $10.1159 / 000320335$

Antony-Debre, I., Bluteau, D., Itzykson, R., Baccini, V., Renneville, A., Boehlen, F., et al. (2012). MYH10 protein expression in platelets as a biomarker of RUNX1 and FLI1 alterations. Blood 120, 2719-2722. doi: 10.1182/blood-201204-422352

Arii, J., Goto, H., Suenega, T., Oyama, M., Kozuka-Hata, H., Imai, T., et al. (2010). Non-muscle myosin IIA is a functional entry receptor for herpes simplex virus1. Nature 467, 859-862. doi: 10.1038/nature09420

Badyal, S. K., Basran, J., Bhanji, N., Kim, J. H., Chavda, A. P., Jung, H. S., et al. (2011). Mechanism of the $\mathrm{Ca}(2)+$-dependent interaction between S100A4 and tail fragments of nonmuscle myosin heavy chain IIA. J. Mol. Biol. 405, 1004-1026. doi: 10.1016/j.jmb.2010.11.036

Bagshaw, C. R. (1993). Muscle Contraction. 2nd Edn. London: Chapman and Hill. Balduini, C. L., Pecci, A., and Savoia, A. (2011). Recent advances in the understanding and management of MYH9-related inherited thrombocytopenias. $\mathrm{Br}$. J. Haematol. 154, 161-174. doi: 10.1111/j.1365-2141.2011.08716.x

Barylko, B., Tooth, P., and Kendrick-Jones, J. (1986). Proteolytic fragmentation of brain myosin and localisation of the heavy-chain phosphorylation site. Eur. J. Biochem. 158, 271-282. doi: 10.1111/j.1432-1033.1986.tb09747.x

Beach, R. J., Licate, S. L., Crish, F. J., and Egelhoff, T. T. (2011). Analysis of the role of Ser1/Ser2/Thr9 phosphorylation on myosin II assembly and function in live cells. BMC Cell Biol. 12:52. doi: 10.1186/1471-2121-12-52

Berg, J. S., Powell, B. C., and Cheney, R. E. (2001). A millennial myosin census. Mol. Biol. Cell 12, 780-794. doi: 10.1091/mbc.12.4.780

Betapudi, V. (2010). Myosin II motor proteins with different functions determine the fate of lamellipodia extension during cell spreading. PLOS ONE 5:e8560. doi: 10.1371/journal.pone.0008560

Betapudi, V., and Egelhoff, T. T. (2009). Roles of an unconventional protein kinase and myosin II in amoeba osmotic shock responses. Traffic 10, 1773-1784. doi: 10.1111/j.1600-0854.2009.00992.x

Betapudi, V., Gokulrangan, G., Chance, M. R., and Egelhoff, T. T. (2011). A proteomic study of myosin II motor proteins during tumor cell migration. J. Mol. Biol. 407, 673-686. doi: 10.1016/j.jmb.2011.02.010

Betapudi, V., Licate, L. S., and Egelhoff, T. T. (2006). Distinct roles of nonmuscle myosin II isoforms in the regulation of MDA-MB-231 breast cancer cell spreading and migration. Cancer Res. 66, 4725-4733. doi: 10.1158/00085472.CAN-05-4236

Betapudi, V., Mason, C., Licate, L., and Egelhoff, T. T. (2005). Identification and characterization of a novel alpha-kinase with a von Willebrand factor A-like motif localized to the contractile vacuole and Golgi complex in Dictyostelium discoideum. Mol. Biol. Cell 16, 2248-2262. doi: 10.1091/mbc.E04-07-0639 
Betapudi, V., Rai, V., Beach, J. R., and Egelhoff, T. (2010). Novel regulation and dynamics of myosin II activation during epidermal wound responses. Exp. Cell Res. 316, 980-991. doi: 10.1016/j.yexcr.2010.01.024

Betschinger, J., Eisenhaber, F., and Knoblich, J. A. (2005). Phosphorylation-induced autoinhibition regulates the cytoskeletal protein Lethal (2) giant larvae. Curr. Biol. 15, 276-282. doi: 10.1016/j.cub.2005.01.012

Boye, K., and Maelandsmo, G. M. (2010). S100A4 and metastasis: a small actor playing many roles. Am. J. Pathol. 176, 528-535. doi: 10.2353/ajpath.2010.090526

Brown, M. E., and Bridgman, P. C. (2003). Retrograde flow rate is increased in growth cones from myosin IIB knockout mice. J. Cell Sci. 116, 1087-1094. doi: $10.1242 /$ jcs. 00335

Bryce, N. S., Schevzov, G., Ferguson, V., Percival, J. M., Lin, J. J. Matsumura, F., et al. (2003). Specification of actin filament function and molecular composition by tropomyosin isoforms. Mol. Biol. Cell 14, 1002-1016. doi: 10.1091/mbc.E02-040244

Burt, R. A., Joseph, J. E., Milliken, S., Collinge, J. E., and Kile, B. T. (2008). Description of a novel mutation leading to MYH9-related disease. Thromb. Res. 122, 861-863. doi: 10.1016/j.thromres.2008.06.011

Bustamante, C., Chemla, Y. R., Forde, N. R., and Izhaky, D. (2004). Mechanical processes in biochemistry. Annu. Rev. Biochem. 73, 705-748. doi: 10.1146/annurev.biochem.72.121801.161542

Casadei, J. M., Gordon, R. D., Lampson, L. A., Schotland, D. L., and Barchi, R. L. (1984). Monoclonal antibodies against the voltage-sensitive $\mathrm{Na}^{+}$channel from mammalian skeletal muscle. Proc. Natl. Acad. Sci. U.S.A. 81, 6227-6231. doi: 10.1073/pnas.81.19.6227

Chakravorty, S., Vu, H., Foelber, V., and Vigoreaux, J. O. (2014). Mutations of the Drosophila myosin regulatory light chain affect courtship song and reduce reproductive success. PLOS ONE 9:e90077. doi: 10.1371/journal.pone. 0090077

Chen, A. K., Chen, X., Lim, Y. M., Reuveny, S., and Oh, S. K. (2014). Inhibition of ROCK-myosin II signaling pathway enables culturing of human pluripotent stem cells on microcarriers without extracellular matrix coating. Tissue Eng. Part C Methods 20, 227-238. doi: 10.1089/ten.tec. 2013.0191

Chen, P., Ostrow, B. D., Tafuri, S. R., and Chisholm, R. L. (1994). Targeted disruption of the Dictyostelium RMLC gene produces cells defective in cytokinesis and development. J. Cell Biol. 127, 1933-1944. doi: 10.1083/jcb. 127.6.1933

Chen, Z., Naveiras, O., Balduini, A., Mammoto, A., Conti, M. A., Adelstein, R. S., et al. (2007). The May-Hegglin anomaly gene MYH9 is a negative regulator of platelet biogenesis modulated by the Rho-ROCK pathway. Blood 110, 171-179. doi: 10.1182/blood-2007-02-071589

Cheney, R. E., and Mooseker, M. S. (1992). Unconventional myosins. Curr. Opin. Cell Biol. 4, 27-35. doi: 10.1016/0955-0674(92)90055-H

Choi, B. O., Kang, S. H., Hyun, Y. S., Kanwal, S., Park, S. W., Koo, H., et al. (2011). A complex phenotype of peripheral neuropathy, myopathy, hoarseness, and hearing loss is linked to an autosomal dominant mutation in MYH14. Hum. Mutat. 32, 669-677. doi: 10.1002/humu.21488

Clark, K., Middelbeek, J., Dorovkov, M. V., Figdor, C. G., Ryazanov, A. G., Lasonder, E., et al. (2008a). The alpha-kinases TRPM6 and TRPM7, but not eEF-2 kinase, phosphorylate the assembly domain of myosin IIA, IIB and IIC. FEBS Lett. 582, 2993-2997. doi: 10.1016/j.febslet.2008.07.043

Clark, K., Middelbeek, J., Lasonder, E., Dulyaninova, N. G., Morrice, N. A., Ryazanov, A. G., et al. (2008b). TRPM7 regulates myosin IIA filament stability and protein localization by heavy chain phosphorylation. J. Mol. Biol. 378, 790-803. doi: 10.1016/j.jmb.2008.02.057

Collins, J. H., and Korn, E. D. (1980). Actin activation of $\mathrm{Ca}^{2+}$-sensitive $\mathrm{Mg}^{2+}$ ATPase activity of Acanthamoeba myosin II is enhanced by dephosphorylation of its heavy chains. J. Biol. Chem. 255, 8011-8014.

Conti, M. A., and Adelstein, R. S. (2008). Nonmuscle myosin II moves in new directions. J. Cell Sci. 121, 11-18. doi: 10.1242/jcs.007112

Conti, M. A., Even-Ram, S., Liu, C., Yamada, K. M., and Adelstein, R. S. (2004). Defects in cell adhesion and the visceral endoderm following ablation of nonmuscle myosin heavy chain II-A in mice. J. Biol. Chem. 279, 41263-41266. doi: 10.1074/jbc.C400352200

Conti, M. A., Sellers, J. R., Adelstein, R. S., and Elzinga, M. (1991). Identification of the serine residue phosphorylated by protein kinase $\mathrm{C}$ in vertebrate nonmuscle myosin heavy chains. Biochemistry 30, 966-970. doi: 10.1021/bi002 $18 \mathrm{a} 012$

Cotman, S. L., and Staropoli, J. F. (2012). The juvenile Batten disease protein, CLN3, and its role in regulating anterograde and retrograde post-Golgi trafficking. Clin. Lipidol. 7, 79-91. doi: 10.2217/clp.11.70

Craig, R., Smith, R., and Kendrick-Jones, J. (1983). Light-chain phosphorylation controls the conformation of vertebrate non-muscle and smooth muscle myosin molecules. Nature 302, 436-439. doi: 10.1038/ $302436 \mathrm{a} 0$

Cross, R. A., Cross, K. E., and Sobieszek, A. (1986). ATP-linked monomer-polymer equilibrium of smooth muscle myosin: the free folded monomer traps ADP.Pi. EMBO J. 5, 2637-2641.

Cross, R. A., Jackson, A. P., Citi, S., Kendrick-Jones, J., and Bagshaw, C. R. (1988). Active site trapping of nucleotide by smooth and nonmuscle myosins. J. Mol. Biol. 203, 173-181. doi: 10.1016/0022-2836(88) 90100-3

Dahan, I., Yearim, A., Touboul, Y., and Ravid, S. (2012). The tumor suppressor Lgl1 regulates NMII-A cellular distribution and focal adhesion morphology to optimize cell migration. Mol. Biol. Cell 23, 591-601. doi: 10.1091/mbc.E11-010015

De, L. C., Mechler, B. M., and Bryant, P. J. (1999). What is Drosophila telling us about cancer? Cancer Metastasis Rev. 18, 295-311.

De, L. H., de Blois, M. C., Vekemans, M., Sidi, D., Villain, E., Kindermans, C., et al. (2001). beta(1)-adrenergic antagonists improve sleep and behavioural disturbances in a circadian disorder, Smith-Magenis syndrome. J. Med. Genet. 38, 586-590. doi: 10.1136/jmg.38.9.586

De, R. D., Zieger, B., Platokouki, H., Heller, P. G., Pastore, A., Bottega, R., et al. (2013). MYH9-related disease: five novel mutations expanding the spectrum of causative mutations and confirming genotype/phenotype correlations. Eur. J. Med. Genet. 56, 7-12. doi: 10.1016/j.ejmg.2012. 10.009

De la Roche, M. A., Smith, J. L., Betapudi, V., Egelhoff, T. T., and Cote, G. P. (2002). Signaling pathways regulating Dictyostelium myosin II. J. Muscle Res. Cell Motil. 23, 703-718. doi: 10.1023/A:1024467426244

Derycke, L., Stove, C., Vercoutter-Edouart, A. S., De, W. O., Dolle, L., Colpaert, N., et al. (2011). The role of non-muscle myosin IIA in aggregation and invasion of human MCF-7 breast cancer cells. Int. J. Dev. Biol. 55, 835-840. doi: 10.1387/ijdb.113336ld

Donaudy, F., Snoeckx, R., Pfister, M., Zenner, H. P., Blin, N., Di, S. M., et al. (2004). Nonmuscle myosin heavy-chain gene MYH14 is expressed in cochlea and mutated in patients affected by autosomal dominant hearing impairment (DFNA4). Am. J. Hum. Genet. 74, 770-776. doi: 10.1086/383285

Drennan, D., and Ryazanov, A. G. (2004). Alpha-kinases: analysis of the family and comparison with conventional protein kinases. Prog. Biophys. Mol. Biol. 85, 1-32. doi: 10.1016/S0079-6107(03)00060-9

Du, M., Wang, G., Ismail, T. M., Gross, S., Fernig, D. G., Barraclough, R., et al. (2012). S100P dissociates myosin IIA filaments and focal adhesion sites to reduce cell adhesion and enhance cell migration. J. Biol. Chem. 287, 15330-15344. doi: 10.1074/jbc.M112.349787

Dudek, S. M., Jacobson, J. R., Chiang, E. T., Birukov, K. G., Wang, P., Zhan, X., et al. (2004). Pulmonary endothelial cell barrier enhancement by sphingosine 1-phosphate: roles for cortactin and myosin light chain kinase. J. Biol. Chem. 279, 24692-24700. doi: 10.1074/jbc.M313969200

Dulyaninova, N. G., and Bresnick, A. R. (2013). The heavy chain has its day: regulation of myosin-II assembly. Bioarchitecture 3, 77-85. doi: 10.4161/ bioa. 26133

Dulyaninova, N. G., Malashkevich, V. N., Almo, S. C., and Bresnick, A. R. (2005). Regulation of myosin-IIA assembly and Mts1 binding by heavy chain phosphorylation. Biochemistry 44, 6867-6876. doi: 10.1021/ bi0500776

Egelhoff, T. T., Croft, D., and Steimle, P. A. (2005). Actin activation of myosin heavy chain kinase A in Dictyostelium: a biochemical mechanism for the spatial regulation of myosin II filament disassembly. J. Biol. Chem. 280, 2879-2887. doi: 10.1074/jbc.M410803200

Egelhoff, T. T., Lee, R. J., and Spudich, J. A. (1993). Dictyostelium myosin heavy chain phosphorylation sites regulate myosin filament assembly and localization in vivo. Cell 75, 363-371. doi: 10.1016/0092-8674(93) 80077-R 
Engelhardt, W. A., and Liubimova, M. N. (1994). [Myosin and adenosine triphosphatase (Nature, 144, 688, Oct. 14, 1939)]. Mol. Biol. (Mosk.) 28, 1229-1230.

Even-Faitelson, L., and Ravid, S. (2006). PAK1 and aPKCzeta regulate myosin II-B phosphorylation: a novel signaling pathway regulating filament assembly. Mol. Biol. Cell 17, 2869-2881. doi: 10.1091/mbc.E05-11-1001

Flores, C., Ma, S. F., Maresso, K., Ober, C., and Garcia, J. G. (2007). A variant of the myosin light chain kinase gene is associated with severe asthma in African Americans. Genet. Epidemiol. 31, 296-305. doi: 10.1002/gepi.20210

Flynn, P. G., and Helfman, D. M. (2010). Non-muscle myosin IIB helps mediate TNF cell death signaling independent of actomyosin contractility (AMC). J. Cell Biochem. 110, 1365-1375. doi: 10.1002/jcb.22653

Ford, H. L., Silver, D. L., Kachar, B., Sellers, J. R., and Zain, S. B. (1997). Effect of Mts1 on the structure and activity of nonmuscle myosin II. Biochemistry 36, 16321-16327. doi: 10.1021/bi9711821

Foth, B. J., Goedecke, M. C., and Soldati, D. (2006). New insights into myosin evolution and classification. Proc. Natl. Acad. Sci. U.S.A. 103, 3681-3686. doi: 10.1073/pnas.0506307103

Gao, L., Flores, C., Fan-Ma, S., Miller, E. J., Moitra, J., Moreno, L., et al. (2007). Macrophage migration inhibitory factor in acute lung injury: expression, biomarker, and associations. Transl. Res. 150, 18-29. doi: 10.1016/j.trsl.2007.02.007

Gao, L., Grant, A., Halder, I., Brower, R., Sevransky, J., Maloney, J. P., et al. (2006). Novel polymorphisms in the myosin light chain kinase gene confer risk for acute lung injury. Am. J. Respir. Cell Mol. Biol. 34, 487-495. doi: 10.1165/rcmb.20050404OC

Gazda, L., Pokrzywa, W., Hellerschmied, D., Lowe, T., Forne, I., Mueller-Planitz, F., et al. (2013). The myosin chaperone UNC-45 is organized in tandem modules to support myofilament formation in C. elegans. Cell 152, 183-195. doi: 10.1016/j.cell.2012.12.025

Getty, A. L., Benedict, J. W., and Pearce, D. A. (2011). A novel interaction of CLN3 with nonmuscle myosin-IIB and defects in cell motility of $\mathrm{Cln} 3(-/-)$ cells. Exp. Cell Res. 317, 51-69. doi: 10.1016/j.yexcr.2010.09.007

Golomb, E., Ma, X., Jana, S. S., Preston, Y. A., Kawamoto, S., Shoham, N. G., et al. (2004). Identification and characterization of nonmuscle myosin II-C, a new member of the myosin II family. J. Biol. Chem. 279, 2800-2808. doi: 10.1074/jbc.M309981200

Greenman, C., Stephens, P., Smith, R., Dalgliesh, G. L., Hunter, C., Bignell, G., et al. (2007). Patterns of somatic mutation in human cancer genomes. Nature 446, 153-158. doi: 10.1038/nature05610

Griffith, L. M., Downs, S. M., and Spudich, J. A. (1987). Myosin light chain kinase and myosin light chain phosphatase from Dictyostelium: effects of reversible phosphorylation on myosin structure and function. J. Cell Biol. 104, 1309-1323. doi: $10.1083 /$ jcb.104.5.1309

Gupton, S. L., and Waterman-Storer, C. M. (2006). Spatiotemporal feedback between actomyosin and focal-adhesion systems optimizes rapid cell migration. Cell 125, 1361-1374. doi: 10.1016/j.cell.2006.05.029

Haigo, S. L., Hildebrand, J. D., Harland, R. M., and Wallingford, J. B. (2003). Shroom induces apical constriction and is required for hingepoint formation during neural tube closure. Curr. Biol. 13, 2125-2137. doi: 10.1016/j.cub.2003.11.054

Hays, T., D’Agati, V. D., Garellek, J. A., Warren, T., Trubin, M. E., Hyink, D. P., et al. (2012). Glomerular MYH9 expression is reduced by HIV-1. AIDS 26, 797-803. doi: 10.1097/QAD.0b013e328351f6cf

Heintzelman, M. B., and Schwartzman, J. D. (1997). A novel class of unconventional myosins from Toxoplasma gondii. J. Mol. Biol. 271, 139-146. doi: 10.1006/jmbi.1997.1167

Hellerschmied, D., and Clausen, T. (2013). Myosin chaperones. Curr. Opin. Struct. Biol. 25C, 9-15. doi: 10.1016/j.sbi.2013.11.002

Hildebrand, J. D. (2005). Shroom regulates epithelial cell shape via the apical positioning of an actomyosin network. J. Cell Sci. 118, 5191-5203. doi: $10.1242 /$ jcs. 02626

Hosono, Y., Usukura, J., Yamaguchi, T., Yanagisawa, K., Suzuki, M., and Takahashi, T. (2012). MYBPH inhibits NM IIA assembly via direct interaction with NMHC IIA and reduces cell motility. Biochem. Biophys. Res. Commun. 428, 173-178. doi: 10.1016/j.bbrc.2012.10.036

Howard, J. (2014). Jonathon Howard: motor proteins go walkabout. Interview by Caitlin Sedwick. J. Cell Biol. 204, 150-151. doi: 10.1083/jcb. 2042pi
Jorgensen, R., Ortiz, P. A., Carr-Schmid, A., Nissen, P., Kinzy, T. G., and Andersen, G. R. (2003). Two crystal structures demonstrate large conformational changes in the eukaryotic ribosomal translocase. Nat. Struct. Biol. 10, 379-385. doi: $10.1038 / \mathrm{nsb} 923$

Jung, H. S., Burgess, S. A., Billington, N., Colegrave, M., Patel, H., Chalovich, J. M., et al. (2008). Conservation of the regulated structure of folded myosin 2 in species separated by at least 600 million years of independent evolution. Proc. Natl. Acad. Sci. U.S.A. 105, 6022-6026. doi: 10.1073/pnas. 0707846105

Kabir, A. M., Kakugo, A., Gong, J. P., and Osada, Y. (2011). How to integrate biological motors towards bio-actuators fueled by ATP. Macromol. Biosci. 11, 1314-1324. doi: 10.1002/mabi.201100060

Kalmes, A., Merdes, G., Neumann, B., Strand, D., and Mechler, B. M. (1996). A serine-kinase associated with the p127-1(2)gl tumour suppressor of Drosophila may regulate the binding of p127 to nonmuscle myosin II heavy chain and the attachment of p127 to the plasma membrane. J. Cell Sci. 109(Pt 6), 1359-1368.

Kawamoto, S. (1994). Evidence for an internal regulatory region in a human nonmuscle myosin heavy chain gene. J. Biol. Chem. 269, 15101-15110.

Kawamoto, S., and Adelstein, R. S. (1991). Chicken nonmuscle myosin heavy chains: differential expression of two mRNAs and evidence for two different polypeptides. J. Cell Biol. 112, 915-924. doi: 10.1083/jcb. 112.5.915

Kelley, M. J., Jawien, W., Ortel, T. L., and Korczak, J. F. (2000). Mutation of MYH9, encoding non-muscle myosin heavy chain A, in May-Hegglin anomaly. Nat. Genet. 26, 106-108. doi: 10.1038/79069

Kim, J. H., and Adelstein, R. S. (2011). LPA(1) -induced migration requires nonmuscle myosin II light chain phosphorylation in breast cancer cells. J. Cell. Physiol. 226, 2881-2893. doi: 10.1002/jcp.22631

Kim, J. H., Wang, A., Conti, M. A., and Adelstein, R. S. (2012). Nonmuscle myosin II is required for internalization of the epidermal growth factor receptor and modulation of downstream signaling. J. Biol. Chem. 287, 27345-27358. doi: 10.1074/jbc.M111.304824

Kimura, K., Ito, M., Amano, M., Chihara, K., Fukata, Y., Nakafuku, M., et al. (1996). Regulation of myosin phosphatase by Rho and Rho-associated kinase (Rho-kinase). Science 273, 245-248. doi: 10.1126/science.273.5272.245

Kiss, B., Duelli, A., Radnai, L., Kekesi, K. A., Katona, G., and Nyitray, L. (2012). Crystal structure of the S100A4-nonmuscle myosin IIA tail fragment complex reveals an asymmetric target binding mechanism. Proc. Natl. Acad. Sci. U.S.A. 109, 6048-6053. doi: 10.1073/pnas. 1114732109

Kolomeisky, A. B. (2013). Motor proteins and molecular motors: how to operate machines at the nanoscale. J. Phys. Condens. Matter 25:463101. doi: 10.1088/0953-8984/25/46/463101

Koyama, K., Fukushima, Y., Inazawa, J., Tomotsune, D., Takahashi, N., Nakamura, Y., et al. (1996). The human homologue of the murine Llglh gene (LLGL) maps within the Smith-Magenis syndrome region in 17p11.2. Cytogenet. Cell Genet. $72,78-82$.

Kriajevska, M. V., Cardenas, M. N., Grigorian, M. S., Ambartsumian, N. S., Georgiev, G. P., and Lukanidin, E. M. (1994). Non-muscle myosin heavy chain as a possible target for protein encoded by metastasis-related mts-1 gene. J. Biol. Chem. 269, 19679-19682.

Krzyzaniak, M. A., Zumstein, M. T., Gerez, J. A., Picotti, P., and Helenius, A. (2013). Host cell entry of respiratory syncytial virus involves macropinocytosis followed by proteolytic activation of the F protein. PLoS. Pathog. 9:e1003309. doi: 10.1371/journal.ppat.1003309

Kuczmarski, E. R., and Spudich, J. A. (1980). Regulation of myosin self-assembly: phosphorylation of Dictyostelium heavy chain inhibits formation of thick filaments. Proc. Natl. Acad. Sci. U.S.A. 77, 7292-7296. doi: 10.1073/pnas.77. 12.7292

Kumar, A., Agarwal, S., Agarwal, D., and Phadke, S. R. (2013). Myotonic dystrophy type 1 (DM1): a triplet repeat expansion disorder. Gene 522, 226-230. doi: 10.1016/j.gene.2013.03.059

Kuznicki, J., Albanesi, J. P., Cote, G. P., and Korn, E. D. (1983). Supramolecular regulation of the actin-activated ATPase activity of filaments of Acanthamoeba Myosin II. J. Biol. Chem. 258, 6011-6014.

Lamant, L., Gascoyne, R. D., Duplantier, M. M., Armstrong, F., Raghab, A., Chhanabhai, M., et al. (2003). Non-muscle myosin heavy chain (MYH9): a new 
partner fused to ALK in anaplastic large cell lymphoma. Genes Chromosomes Cancer 37, 427-432. doi: 10.1002/gcc.10232

Leal, A., Endele, S., Stengel, C., Huehne, K., Loetterle, J., Barrantes, R., et al. (2003). A novel myosin heavy chain gene in human chromosome 19q13.3. Gene 312, 165-171. doi: 10.1016/S0378-1119(03)00613-9

Lehmann, M. J., Sherer, N. M., Marks, C. B., Pypaert, M., and Mothes, W. (2005). Actin- and myosin-driven movement of viruses along filopodia precedes their entry into cells. J. Cell Biol. 170, 317-325. doi: 10.1083/jcb. 200503059

Leung, T., Chen, X. Q., Manser, E., and Lim, L. (1996). The p160 RhoAbinding kinase ROK alpha is a member of a kinase family and is involved in the reorganization of the cytoskeleton. Mol. Cell Biol. 16, 5313-5327.

Li, Z. H., Spektor, A., Varlamova, O., and Bresnick, A. R. (2003). Mtsl regulates the assembly of nonmuscle myosin-IIA. Biochemistry 42, 14258-14266. doi: 10.1021/bi0354379

Liu, X., Ito, K., Morimoto, S., Hikkoshi-Iwane, A., Yanagida, T., and Uyeda, T. Q. (1998). Filament structure as an essential factor for regulation of Dictyostelium myosin by regulatory light chain phosphorylation. Proc. Natl. Acad. Sci. U.S.A. 95, 14124-14129. doi: 10.1073/pnas.95.24.14124

Luck-Vielmetter, D., Schleicher, M., Grabatin, B., Wippler, J., and Gerisch, G. (1990). Replacement of threonine residues by serine and alanine in a phosphorylatable heavy chain fragment of Dictyostelium myosin II. FEBS Lett. 269, 239-243. doi: 10.1016/0014-5793(90)81163-I

Ma, X., Jana, S. S., Conti, M. A., Kawamoto, S., Claycomb, W. C., and Adelstein, R. S. (2010). Ablation of nonmuscle myosin II-B and II-C reveals a role for nonmuscle myosin II in cardiac myocyte karyokinesis. Mol. Biol. Cell 21, 3952-3962. doi: $10.1091 / \mathrm{mbc} . E 10-04-0293$

Maravillas-Montero, J. L., and Santos-Argumedo, L. (2012). The myosin family: unconventional roles of actin-dependent molecular motors in immune cells. J. Leukoc. Biol. 91, 35-46. doi: 10.1189/jlb.0711335

Matsumura, F. (2005). Regulation of myosin II during cytokinesis in higher eukaryotes. Trends Cell Biol. 15, 371-377. doi: 10.1016/j.tcb.2005. 05.004

Matsumura, F., and Hartshorne, D. J. (2008). Myosin phosphatase target subunit: many roles in cell function. Biochem. Biophys. Res. Commun. 369, 149-156. doi: 10.1016/j.bbrc.2007.12.090

Matsuoka, R., Yoshida, M. C., Furutani, Y., Imamura, S., Kanda, N., Yanagisawa, M., et al. (1993). Human smooth muscle myosin heavy chain gene mapped to chromosomal region 16q12. Am. J. Med. Genet. 46, 61-67. doi: 10.1002/ajmg.1320460110

Mene, P., Punzo, G., and Pirozzi, N. (2013). TRP channels as therapeutic targets in kidney disease and hypertension. Curr. Top. Med. Chem. 13, 386-397. doi: $10.2174 / 1568026611313030013$

Middelbeek, J., Clark, K., Venselaar, H., Huynen, M. A., and van Leeuwen, F. N. (2010). The alpha-kinase family: an exceptional branch on the protein kinase tree. Cell Mol. Life Sci. 67, 875-890. doi: 10.1007/s00018-009-0215-Z

Min, S. Y., Ahn, H. J., Park, W. S., and Kim, J. W. (2014). Successful renal transplantation in MYH9-related disorder with severe macrothrombocytopenia: first report in Korea. Transplant. Proc. 46, 654-656. doi: 10.1016/j.transproceed.2013.11.144

Mitsuhashi, M., Sakata, H., Kinjo, M., Yazawa, M., and Takahashi, M. (2011). Dynamic assembly properties of nonmuscle myosin II isoforms revealed by combination of fluorescence correlation spectroscopy and fluorescence cross-correlation spectroscopy. J. Biochem. 149, 253-263. doi: 10.1093/jb/ mvq134

Murakami, N., Chauhan, V. P., and Elzinga, M. (1998). Two nonmuscle myosin II heavy chain isoforms expressed in rabbit brains: filament forming properties, the effects of phosphorylation by protein kinase C and casein kinase II, and location of the phosphorylation sites. Biochemistry 37, 1989-2003. doi: 10.1021/bi971959a

Murata-Hori, M., Suizu, F., Iwasaki, T., Kikuchi, A., and Hosoya, H. (1999). ZIP kinase identified as a novel myosin regulatory light chain kinase in HeLa cells. FEBS Lett. 451, 81-84. doi: 10.1016/S0014-5793(99)00550-5

Nishikawa, M., Sellers, J. R., Adelstein, R. S., and Hidaka, H. (1984). Protein kinase $\mathrm{C}$ modulates in vitro phosphorylation of the smooth muscle heavy meromyosin by myosin light chain kinase. J. Biol. Chem. 259, 8808-8814.
Odronitz, F., Hellkamp, M., and Kollmar, M. (2007). diArk-a resource for eukaryotic genome research. BMC Genomics 8:103. doi: 10.1186/14712164-8-103

Onishi, H., and Wakabayashi, T. (1982). Electron microscopic studies of myosin molecules from chicken gizzard muscle I: the formation of the intramolecular loop in the myosin tail. J. Biochem. 92, 871-879.

Pasternak, C., Flicker, P. F., Ravid, S., and Spudich, J. A. (1989). Intermolecular versus intramolecular interactions of Dictyostelium myosin: possible regulation by heavy chain phosphorylation. J. Cell Biol. 109, 203-210. doi: 10.1083/jcb.109.1.203

Pastra-Landis, S. C., and Lowey, S. (1986). Myosin subunit interactions. Properties of the 19,000-dalton light chain-deficient myosin. J. Biol. Chem. 261, 14811-14816.

Pecci, A., Klersy, C., Gresele, P., Lee, K. J., De Rocco, D., Bozzi, V., et al. (2014). MYH9-related disease: a novel prognostic model to predict the clinical evolution of the disease based on genotype-phenotype correlations. Hum. Mutat. 35, 236-247. doi: 10.1002/humu.22476

Pecci, A., Panza, E., De Rocco, D., Pujol-Moix, N., Girotto, G., Podda, L., et al. (2010). MYH9 related disease: four novel mutations of the tail domain of myosin-9 correlating with a mild clinical phenotype. Eur. J. Haematol. 84, 291-297. doi: 10.1111/j.1600-0609.2009.01398.x

Pecci, A., Panza, E., Pujol-Moix, N., Klersy, C., Di Bari, F., Bozzi, V., et al. (2008). Position of nonmuscle myosin heavy chain IIA (NMMHC-IIA) mutations predicts the natural history of MYH9-related disease. Hum. Mutat. 29, 409-417. doi: 10.1002/humu.20661

Plant, P. J., Fawcett, J. P., Lin, D. C., Holdorf, A. D., Binns, K., Kulkarni, S., et al. (2003). A polarity complex of mPar-6 and atypical PKC binds, phosphorylates and regulates mammalian Lgl. Nat. Cell Biol. 5, 301-308. doi: 10.1038/ ncb 948

Pollard, T. D., and Korn, E. D. (1973). Acanthamoeba myosin. II. Interaction with actin and with a new cofactor protein required for actin activation of $\mathrm{Mg}^{2+}$ adenosine triphosphatase activity. J. Biol. Chem. 248, 4691-4697.

Rai, V., and Egelhoff, T. T. (2011). Role of B regulatory subunits of protein phosphatase type $2 \mathrm{~A}$ in myosin II assembly control in Dictyostelium discoideum. Eukaryot. Cell 10, 604-610. doi: 10.1128/EC.00296-10

Ramsey, I. S., Delling, M., and Clapham, D. E. (2006). An introduction to TRP channels. Annu. Rev. Physiol. 68, 619-647. doi: 10.1146/annurev.physiol.68.040204.100431

Rey, M., Valenzuela-Fernandez, A., Urzainqui, A., Yanez-Mo, M., Perez-Martinez, M., Penela, P., et al. (2007). Myosin IIA is involved in the endocytosis of CXCR4 induced by SDF-1alpha. J. Cell Sci. 120, 1126-1133. doi: 10.1242/jcs.03415

Richards, T. A., and Cavalier-Smith, T. (2005). Myosin domain evolution and the primary divergence of eukaryotes. Nature 436, 1113-1118. doi: 10.1038 /nature03949

Rinaldi, F., Terracciano, C., Pisani, V., Massa, R., Loro, E., Vergani, L., et al. (2012). Aberrant splicing and expression of the non muscle myosin heavychain gene MYH14 in DM1 muscle tissues. Neurobiol. Dis. 45, 264-271. doi: 10.1016/j.nbd.2011.08.010

Rochlin, M. W., Itoh, K., Adelstein, R. S., and Bridgman, P. C. (1995). Localization of myosin II A and B isoforms in cultured neurons. J. Cell Sci. 108(Pt 12), 3661-3670.

Rodgers, B. D. (2005). Insulin-like growth factor-I downregulates embryonic myosin heavy chain (eMyHC) in myoblast nuclei. Growth Horm. IGF. Res. 15, 377-383. doi: 10.1016/j.ghir.2005.08.001

Ronen, D., and Ravid, S. (2009). Myosin II tailpiece determines its paracrystal structure, filament assembly properties, and cellular localization. J. Biol. Chem. 284, 24948-24957. doi: 10.1074/jbc.M109.023754

Rosenberg, M. M., Ronen, D., Lahav, N., Nazirov, E., Ravid, S., and Friedler, A. (2013). High resolution characterization of myosin IIC protein tailpiece and its effect on filament assembly. J. Biol. Chem. 288, 9779-9789. doi: 10.1074/jbc.M112.430173

Rottbauer, W., Wessels, G., Dahme, T., Just, S., Trano, N., Hassel, D., et al. (2006). Cardiac myosin light chain-2: a novel essential component of thickmyofilament assembly and contractility of the heart. Circ. Res. 99, 323-331. doi: 10.1161/01.RES.0000234807.16034.fe

Runnels, L. W. (2011). TRPM6 and TRPM7: a Mul-TRP-PLIK-cation of channel functions. Curr. Pharm. Biotechnol. 12, 42-53. doi: $10.2174 / 138920111793937880$ 
Ryazanov, A. G., Pavur, K. S., and Dorovkov, M. V. (1999). Alpha-kinases: a new class of protein kinases with a novel catalytic domain. Curr. Biol. 9, R43-R45. doi: 10.1016/S0960-9822(99)80006-2

Sanders, L. C., Matsumura, F., Bokoch, G. M., and de, L. P. (1999). Inhibition of myosin light chain kinase by p21-activated kinase. Science 283, 2083-2085. doi: $10.1126 /$ science.283.5410.2083

Sandquist, J. C., Swenson, K. I., Demali, K. A., Burridge, K., and Means, A. R. (2006). Rho kinase differentially regulates phosphorylation of nonmuscle myosin II isoforms A and B during cell rounding and migration. J. Biol. Chem. 281, 35873-35883. doi: 10.1074/jbc.M605343200

Scheeff, E. D., and Bourne, P. E. (2005). Structural evolution of the protein kinaselike superfamily. PLoS Comput. Biol. 1:e49. doi: 10.1371/journal.pcbi.0010049

Schlingmann, K. P., Weber, S., Peters, M., Niemann Nejsum, L., Vitzthum, H., Klingel, K., et al. (2002). Hypomagnesemia with secondary hypocalcemia is caused by mutations in TRPM6, a new member of the TRPM gene family. Nat Genet. 31, 166-170. doi: 10.1038/ng889

Schramek, D., Sendoel, A., Segal, J. P., Beronja, S., Heller, E., Oristian, D., et al. (2014). Direct in vivo RNAi screen unveils myosin IIa as a tumor suppressor of squamous cell carcinomas. Science 343, 309-313. doi: 10.1126/science. 1248627

Sellers, J. R., Eisenberg, E., and Adelstein, R. S. (1982). The binding of smooth muscle heavy meromyosin to actin in the presence of ATP. Effect of phosphorylation. J. Biol. Chem. 257, 13880-13883.

Sharma-Walia, N., Paul, A. G., Bottero, V., Sadagopan, S., Veettil, M. V., Kerur, N., et al. (2010). Kaposi's sarcoma associated herpes virus (KSHV) induced COX-2: a key factor in latency, inflammation, angiogenesis, cell survival and invasion. PLoS Pathog. 6:e1000777. doi: 10.1371/journal.ppat. 1000777

Shin, D. H., Chun, Y. S., Lee, D. S., Huang, L. E., and Park, J. W. (2008). Bortezomib inhibits tumor adaptation to hypoxia by stimulating the FIHmediated repression of hypoxia-inducible factor-1. Blood 111, 3131-3136. doi: 10.1182/blood-2007-11-120576

Shutova, M., Yang, C., Vasiliev, J. M., and Svitkina, T. (2012). Functions of nonmuscle myosin II in assembly of the cellular contractile system. PLoS ONE 7:e40814 doi: 10.1371/journal.pone.0040814

Simons, M., Wang, M., McBride, O. W., Kawamoto, S., Yamakawa, K., Gdula, D., et al. (1991). Human nonmuscle myosin heavy chains are encoded by two genes located on different chromosomes. Circ. Res. 69, 530-539. doi: 10.1161/01.RES.69.2.530

Slonska, A., Polowy, R., Golke, A., and Cymerys, J. (2012). Role of cytoskeletal motor proteins in viral infection. Postepy Hig. Med. Dosw. (Online) 66, 810-817. doi: $10.5604 / 17322693.1016360$

Smith, A. C., McGavran, L., Robinson, J., Waldstein, G., MacFarlane, J., Zonona, J., et al. (1986). Interstitial deletion of $(17)(\mathrm{p} 11.2 \mathrm{p} 11.2)$ in nine patients. Am. J. Med. Genet. 24, 393-414. doi: 10.1002/ajmg.1320240303

Solinet, S., and Vitale, M. L. (2008). Isoform B of myosin II heavy chain mediates actomyosin contractility during TNFalpha-induced apoptosis. J. Cell Sci. 121, 1681-1692. doi: $10.1242 /$ jcs. 022640

Somlyo, A. P., and Somlyo, A. V. (2003). $\mathrm{Ca}^{2+}$ sensitivity of smooth muscle and nonmuscle myosin II: modulated by G proteins, kinases, and myosin phosphatase. Physiol. Rev. 83, 1325-1358. doi: 10.1152/physrev.00023.2003

Stedman, H. H., Kozyak, B. W., Nelson, A., Thesier, D. M., Su, L. T., Low, D. W., et al. (2004). Myosin gene mutation correlates with anatomical changes in the human lineage. Nature 428, 415-418. doi: 10.1038/nature 02358

Strand, D., Jakobs, R., Merdes, G., Neumann, B., Kalmes, A., Heid, H. W., et al. (1994). The Drosophila lethal(2)giant larvae tumor suppressor protein forms homo-oligomers and is associated with nonmuscle myosin II heavy chain. J. Cell Biol. 127, 1361-1373. doi: 10.1083/jcb.127.5.1361

Su, L. T., Chen, H. C., Gonzalez-Pagan, O., Overton, J. D., Xie, J., Yue, L., et al. (2010). TRPM7 activates m-calpain by stress-dependent stimulation of p38 MAPK and c-Jun N-terminal kinase. J. Mol. Biol. 396, 858-869. doi: 10.1016/j.jmb.2010.01.014

Takizawa, N., Ikebe, R., Ikebe, M., and Luna, E. J. (2007). Supervillin slows cell spreading by facilitating myosin II activation at the cell periphery. J. Cell Sci. 120, 3792-3803. doi: 10.1242/jcs.008219

Tan, I., Yong, J., Dong, J. M., Lim, L., and Leung, T. (2008). A tripartite complex containing MRCK modulates lamellar actomyosin retrograde flow. Cell 135, 123-136. doi: 10.1016/j.cell.2008.09.018
Tan, J. L., and Spudich, J. A. (1990). Dictyostelium myosin light chain kinase. Purification and characterization. J. Biol. Chem. 265, 13818-13824.

Tang, H. W., Wang, Y. B., Wang, S. L., Wu, M. H., Lin, S. Y., and Chen, G. C. (2011). Atg1-mediated myosin II activation regulates autophagosome formation during starvation-induced autophagy. EMBO J. 30, 636-651. doi: 10.1038/emboj.2010.338

Toothaker, L. E., Gonzalez, D. A., Tung, N., Lemons, R. S., Le Beau, M. M. Arnaout, M. A., et al. (1991). Cellular myosin heavy chain in human leukocytes: isolation of $5^{\prime} \mathrm{cDNA}$ clones, characterization of the protein, chromosomal localization, and upregulation during myeloid differentiation. Blood 78, 1826-1833.

Totsukawa, G., Wu, Y., Sasaki, Y., Hartshorne, D. J., Yamakita, Y., Yamashiro, S., et al. (2004). Distinct roles of MLCK and ROCK in the regulation of membrane protrusions and focal adhesion dynamics during cell migration of fibroblasts. J. Cell Biol. 164, 427-439. doi: 10.1083/jcb. 200306172

Trotter, J. A. (1982). Living macrophages phosphorylate the 20,000 Dalton light chains and heavy chains of myosin. Biochem. Biophys. Res. Commun. 106, 1071-1077. doi: 10.1016/0006-291X(82)91820-4

Trotter, J. A., Nixon, C. S., and Johnson, M. A. (1985). The heavy chain of macrophage myosin is phosphorylated at the tip of the tail. J. Biol. Chem. 260, 14374-14378.

Trybus, K. M., Huiatt, T. W., and Lowey, S. (1982). A bent monomeric conformation of myosin from smooth muscle. Proc. Natl. Acad. Sci. U.S.A. 79, 6151-6155. doi: 10.1073/pnas.79.20.6151

Trybus, K. M., and Lowey, S. (1984). Conformational states of smooth muscle myosin. Effects of light chain phosphorylation and ionic strength. J. Biol. Chem. 259, 8564-8571.

Tullio, A. N., Accili, D., Ferrans, V. J., Yu, Z. X., Takeda, K., Grinberg, A., et al. (1997). Nonmuscle myosin II-B is required for normal development of the mouse heart. Proc. Natl. Acad. Sci. U.S.A. 94, 12407-12412. doi: 10.1073/pnas.94.23.12407

Tullio, A. N., Bridgman, P. C., Tresser, N. J., Chan, C. C., Conti, M. A., Adelstein, R. S., et al. (2001). Structural abnormalities develop in the brain after ablation of the gene encoding nonmuscle myosin II-B heavy chain. J. Comp Neurol. 433, 62-74. doi: 10.1002/cne.1125

Underwood, J., Greene, J., and Steimle, P. A. (2010). Identification of a new mechanism for targeting myosin II heavy chain phosphorylation by Dictyostelium myosin heavy chain kinase B. BMC Res. Notes 3:56. doi: 10.1186/17560500-3-56

Uyeda, T. Q., Abramson, P. D., and Spudich, J. A. (1996). The neck region of the myosin motor domain acts as a lever arm to generate movement. Proc. Natl. Acad. Sci. U.S.A. 93, 4459-4464. doi: 10.1073/pnas.93.9.4459

Vaillancourt, J. P., Lyons, C., and Cote, G. P. (1988). Identification of two phosphorylated threonines in the tail region of Dictyostelium myosin II. J. Biol. Chem. 263, 10082-10087.

Vale, R. D. (2003). The molecular motor toolbox for intracellular transport. Cell 112, 467-480. doi: 10.1016/S0092-8674(03)00111-9

van, L. H., Elliott, G., and O'Hare, P. (2002). Evidence of a role for nonmuscle myosin II in herpes simplex virus type 1 egress. J. Virol. 76, 3471-3481. doi: 10.1128/JVI.76.7.3471-3481.2002

van den Heuvel, M. G., Bolhuis, S., and Dekker, C. (2007). Persistence length measurements from stochastic single-microtubule trajectories. Nano Lett. 7, 3138-3144. doi: 10.1021/nl071696y

Varlamova, O., Spektor, A., and Bresnick, A. R. (2001). Protein kinase C mediates phosphorylation of the regulatory light chain of myosin-II during mitosis. J. Muscle Res. Cell Motil. 22, 243-250. doi: 10.1023/A:1012289905754

Vasioukhin, V. (2006). Lethal giant puzzle of Lgl. Dev. Neurosci. 28, 13-24. doi: $10.1159 / 000090749$

von Muhlen, C. A., Chan, E. K., Peebles, C. L., Imai, H., Kiyosawa, K., and Tan, E. M. (1995). Non-muscle myosin as target antigen for human autoantibodies in patients with hepatitis $\mathrm{C}$ virus-associated chronic liver diseases. Clin. Exp. Immunol. 100, 67-74. doi: 10.1111/j.1365-2249.1995.tb03605.x

Walder, R. Y., Landau, D., Meyer, P., Shalev, H., Tsolia, M., Borochowitz, Z., et al. (2002). Mutation of TRPM6 causes familial hypomagnesemia with secondary hypocalcemia. Nat. Genet. 3, 171-174. doi: 10.1038/ng901

Wang, L., Guo, D. C., Cao, J., Gong, L., Kamm, K. E., Regalado, E., et al. (2010). Mutations in myosin light chain kinase cause familial aortic dissections. Am. J. Hum. Genet. 87, 701-707. doi: 10.1016/j.ajhg.2010.10.006 
Wasylnka, J. A., Bakowski, M. A., Szeto, J., Ohlson, M. B., Trimble, W. S., Miller, S. I., et al. (2008). Role for myosin II in regulating positioning of Salmonellacontaining vacuoles and intracellular replication. Infect. Immun. 76, 2722-2735. doi: 10.1128/IAI.00152-08

Weir, L., and Chen, D. (1996). Characterization of the nonmuscle myosin heavy chain IIB promoter: regulation by E2F. Gene Expr. 6, 45-57.

Wendt, T., Taylor, D., Trybus, K. M., and Taylor, K. (2001). Three-dimensional image reconstruction of dephosphorylated smooth muscle heavy meromyosin reveals asymmetry in the interaction between myosin heads and placement of subfragment 2. Proc. Natl. Acad. Sci. U.S.A. 98, 4361-4366. doi: 10.1073/pnas.071051098

Xia, D., Stull, J. T., and Kamm, K. E. (2005). Myosin phosphatase targeting subunit 1 affects cell migration by regulating myosin phosphorylation and actin assembly. Exp. Cell Res. 304, 506-517. doi: 10.1016/j.yexcr.2004.11.025

Xia, Z. K., Yuan, Y. C., Yin, N., Yin, B. L., Tan, Z. P., and Hu, Y. R. (2012). Nonmuscle myosin IIA is associated with poor prognosis of esophageal squamous cancer. Dis. Esophagus 25, 427-436. doi: 10.1111/j.1442-2050.2011.01261.x

Xu, J., Gao, X. P., Ramchandran, R., Zhao, Y. Y., Vogel, S. M., and Malik, A. B. (2008). Nonmuscle myosin light-chain kinase mediates neutrophil transmigration in sepsis-induced lung inflammation by activating beta 2 integrins. Nat. Immunol. 9, 880-886. doi: 10.1038/ni.1628

Xu, X. S., Kuspa, A., Fuller, D., Loomis, W. F., and Knecht, D. A. (1996). Cell-cell adhesion prevents mutant cells lacking myosin II from penetrating aggregation streams of Dictyostelium. Dev. Biol. 175, 218-226. doi: 10.1006/dbio. 1996.0109
Yumura, S., Yoshida, M., Betapudi, V., Licate, L. S., Iwadate, Y., Nagasaki, A., et al. (2005). Multiple myosin II heavy chain kinases: roles in filament assembly control and proper cytokinesis in Dictyostelium. Mol. Biol. Cell 16, 4256-4266. doi: 10.1091/mbc.E05-03-0219

Zamudio-Meza, H., Castillo-Alvarez, A., Gonzalez-Bonilla, C., and Meza, I. (2009). Cross-talk between Rac1 and Cdc42 GTPases regulates formation of filopodia required for dengue virus type-2 entry into HMEC-1 cells. J. Gen. Virol. 90, 2902-2911. doi: 10.1099/vir.0.014159-0

Conflict of Interest Statement: The author declares that the research was conducted in the absence of any commercial or financial relationships that could be construed as a potential conflict of interest.

Received: 20 April 2014; accepted: 19 June 2014; published online: 07 July 2014. Citation: Betapudi V (2014) Life without double-headed non-muscle myosin II motor proteins. Front. Chem. 2:45. doi: 10.3389/fchem.2014.00045

This article was submitted to Cellular Biochemistry, a section of the journal Frontiers in Chemistry.

Copyright (c) 2014 Betapudi. This is an open-access article distributed under the terms of the Creative Commons Attribution License (CCBY). The use, distribution or reproduction in other forums is permitted, provided the original author(s) or licensor are credited and that the original publication in this journal is cited, in accordance with accepted academic practice. No use, distribution or reproduction is permitted which does not comply with these terms. 